DOI https://doi.org/10.18551/rjoas.2018-04.04

\title{
INDONESIAN FOOD POLICY: THE PROGRAMS FOR STRENGTHENING FOOD SELF-SUFFICIENCY IN REFORMATION ERA
}

\author{
Kamrussamad ${ }^{*}$, Wibowo Aris, Suraji, students \\ Ghazali Shafie Graduate School of Government, University Utara Malasyia \\ Embi Muhammad Ali \\ College of Law, Government and International Studies, University Utara Malasyia \\ *E-mail: uumkamrussamad@gmail.com
}

\begin{abstract}
The 2012 decree \#18, the policy on food states that objective of food implementation is to meet basic human needs and provide fair, equitable, and sustainable benefits based on food sovereignty, food self-sufficiency, and national food security. Food sovereignty, independence and security are fundamental and supports implementation of policies related to food implementation in Indonesia. The 2012 decree \#18 stated that food implementation aims to improve ability to produce food independently, provide a variety of food and meet the requirements of security, quality, and nutrition for public consumption.
\end{abstract}

\section{KEY WORDS}

Food policy, security, nutrition quality, consumption.

Rice is staple food in Indonesia. Rice farming is livelihood for majority of Indonesian people. Prawiro (1998) even stated that "...Indonesian economy may as well regareded as rice economy."

Until recently, Indonesia is one of the largest rice-producing countries as well as one of the largest consumers of rice in the world. Official government data shows that rice production in Indonesia. The 2014 national rice production achieved 70.85 million tons or decreased by 0.43 million tons $(0.61 \%)$ compared to that in 2013 . Estimated rice production in 2015 was 75.55 million tons, a 4.70 million tons $(6.64 \%)$ increase compared to that in 2014. There was 1.83 million ton increase of rice production in Java in 2015 and 2.88 million ton increase of rice production outside Java. These occurred due to a 0.51 million hectare $(3.71 \%)$ increase in harvested ricefield and 1.45 quintal/ hectare $(2.82 \%)$ increase in productivity. Based on the National Socioeconomic Survey, average rice consumption is $87.63 \mathrm{kgs} / \mathrm{year}$ or $240 \mathrm{gr} / \mathrm{day}$, while the average rice consumption for household and restaurant based on the the National Bureau of Statistics/ Department of Trade and Industry is $114 \mathrm{kgs} /$ year or 312 grams /day. Third, based on the Ministry of Agriculture, average rice consumption is $124 \mathrm{kgs} / \mathrm{year}$ or $340 \mathrm{grams} /$ day and that based on the National Bureau of Statistics, it is $139 \mathrm{kgs} /$ day or 380 grams /day. These data are higher than the actual rice consumption and therefore, this year the government will establish that estimated rice consumption is 114 kilograms/ year. Using the estimation, the national rice consumption reaches about 27 million tons (National Bureau of Statistics, 2015).

High consumption of rice and the fact that majority of Indonesian people depends upon ricefield as source of their income show how pivotal and strategic role rice has for Indonesian poeople. Not only is rice related to consumer's need, but it also is related to farmers which according to International Fund For Agricultural Development (IFAD) are the largest part of low-income citizens in Indonesia. Rice has also become inseparable part of Indonesian history from the traditional kingdoms, Dutch occupation, the Old Order, the New Order to present time.

Based on the elaboration, the government should guarantee there is adequate supply of rice for consumption.. Based on previous events, lacking supply of rice will automatically result in food cisis. Food crisis will cause nutrition, health, economics and even political 
crisis. The government should take certain preventive measures in order to prevent negative impacts of food crisis.

Besides that, food security is also defined as affordability that is closely related to efforts to improve quality of human resources. Without qualified food, it is impossible to produce competent human resources. Therefore, developing a robust food security system is requirement for the national development. In developing food security system, main actors involved are business persons, producers, processors and traders; most of whom are small entrepreneurs. Therefore, efforts to increase and stabilize food security should focus on empowering small business allowing them to become self-reliant and be able to develop agriculture sustainably. In order to improve food security, the government should play roles as facilitator, policy-maker, and accelerator developing farmer's ability in agriculture.

Vocal point of the 2012 Decree number 18 is alarming need to establish institutions authorized for coordination, policy-making, and providing guidances to different ministries/ institutions related to food security policies and programs. Article 126 of food-related regulation the House of Representatives issued in October 2012 states "in order to achieve food sovereignty, food self-sufficiency and national food security, food-related public institutions should report to the President." The article then stated that "such public institutions are responsible for implementation of food-related government programs."

Due to their strategic positions, it is expected that the public institutions responsible for food authority can avoid conflict of interest of related sectoral ego. We expect that these institutions become more independent because they are responsible for not only establishing food-related policy but also being food operator. They are responsible for national food supply, production, storage and distribution.

It proves how much responsibility both central and regional government have to make sure that national food implementation programs are well-organized, effective and efficient. The government should empower potentials all stakeholders have to carry out effective and efficient food implementation that is able to overcome recent and future challenge.

Food challenges are increasingly complex, constantly changing from time to time and affected by specific, local and global phenomena. Changes and discrepancy such as the actual condition of the society, social dynamics, advances of technology, information revolution, telecommunication, transportation, democratization, decentralization and globalization are food determinants we have to analyze as foundations for national anticipation.

\section{LITERATURE REVIEW}

Each expert has his or her own definition about public policy. It occurs because these experts have different prespectives and focus of analysis. In general, these diverseddefinitions can be classified into two point-of-views: The first is point-of-view that treats all public policies as equal and the second one is poit-of-view focusing on implementation of policy.

The second point-of-view is then divided into two categories. The first category considers public policy as government decisions that have particular objectives or targets while the other category considers public policy as government decision which has anticipated or predicted effects (compared to Solihin Abdul Wahab $(1990: 31,32)$ and Agus Dwiyanto (1994).

The first category is represented by ideas of Thomas R. Dye, C. Edwards III and Sharkansky, Davis Eston, as well as James E. Anderson, while Nakamura and Small Wood as well as Presman and Wildavsky are the experts whose ideas represent the second category.

Dye defines public policy as "anything the government has decided to apply or not to apply" (as cited in Winarno, 2004: 2). Furthermore, Dye (Irfan Islamy, 1994:18) explained that:

"When government has made decision to carry out an action, they should be certain that the action carries out certain purpose previously. Public policy should involve all 
government "programs" and should not only represent the government or government apparatus interest. Besides that, an action the government decides not to carry out can also be categorized as public policy since such action has equal effect as the government programs...".

Edwards and Sharkansky (Islamy:18) defined public policy as "anything the government has stated and conducted or not conducted. Public policy refers to target and goals of the government programs ...." They further emphasized that "public policy is stated clearly in government regulations or government apparatus' speeches or programs and actions carried out by the government " (Islamy:19).

Eston defined public policy as "an act to forcefully allocate value to members of the society." Furthermore: "legitimate government is the only institution who has authority to conduct programs affecting the society and the legitimate government's decision-making is represented into value applicable in the society." (Islamy: 20).

Anderson (as cited in Winarno, 2004: 3) defined policy as "a program of which objectives have been established by one or a group of actors in order to overcome certain issue." Public policy is formulated as "policies developed by public institutions or government apparatus."Anderson explained that this public policy concept imply that (1) policy has always had particular objectives or refers to a goal-oriented action; (2) policy consists of government apparatus' actions or pattern of their actions; (3) instead of program or discourse, policy is real action carried out by the government; (4) public policy has positive effect in terms that it represents government effort to overcome certain issues. It may also have negative impact when the government has decided not to take certain action against particular issues; and (5) public policy is at least based on regulations and authoritative in nature.

The second perspective is reflected into the definitions formulated by experts such as Nakamura and Small Wood, as well as Presman and Wildavsky among others. According Nakamura and Wood (as cited in Wahab: 32) "public policy is series of instructions/mandate policy-maker establish and administrators are the ones carry out these instructions as well as explain their objectives and methods to achieve those objectives." The basis is conception that "public policy should involve policy implementation design." Despite having diverseddefinition, in macro-level public policy has one orientation that is public interest (society). In relation to this, Islamy postulated that:

"..... it can be concluded that public policy refers to series of public-oriented actions the government has decided to apply or not."

In the context of public policy analysis, policy implementation is an important and strategic aspect. "Important" is closely related to Grindle (Wahab)'s idea that:

"Policy implementation is not only related to description of political decisions into routine procedures through channel of bureaucracy; instead, it is related to conflict, decision and who gets what from a policy implementation."

On the other hand "strategic" is closely related to formulation of political decision into routine procedures through channel of bureaucracy, conflicts, decision-making and who gets what from particular policy implementation. Strategic is also related to its function and role as "mediating variable" connecting objective and outcome of a policy. It means policy implementation refers to how successful administration of a policy is (outcome). Wahab described that :

"In general, implementation aims to develop a system in which public policy objectives and targets are formulate into government programs (outcomes). Therefore, implementation involves what the policy science called Policy Delivery System of which result consist of specific procedures or means to achieve particular purpose/ target".

Due to its relevant and strategic nature, policy implementation is considered as the most challenging aspect of public policy. Bardach (1984: 293), for example, described that:

"It is quite a challenge to design public program and public policy. It is even more challenging to find convincing terminology or jargons for the decision-makers to listen to. The most challenging step is to carry the programs or public policy in a way that meets everyone's expectation including those considered as clients". 
Developing countries, in particular, struggle to carry out their public policy. In the thirdworld country, public policy implementation is the largest obstacle for development in social and economic sector ( Smit 1973: Grindle, 1980, dalam Wahab:150). "Government of the third-world country is unable to plan, design and establish either public policy or development programs" (Myrdal, as cited in Wahab: 1990). Despite of being significant, strategic and sophisticated, public policy implementation initially does not attract attention of politicians, scholar or practitioners due to some of the reasons Winarno (2004 : 67) explained as follow:

"This devotion is partly based on naive assumption, stated in numerous studies that once public pulicy has been issued, administator has responsibility to apply the policy and makes sure objectives of the policy, policy-makers had formulated previously, can be achieved. Implementation is regareded as series of decisions and interaction that look for political substance. There is assumption that policy implementation is less-than-complex process and does not involve promoinent issues.

Recently, developing countries has started to pay attention to their public policy sector since facts on the field reveal less-than-stellar policy implementation or even failure in implementation of several vital policies.

Winarno (2004: 171) stated that policy implementation has several considerable impacts. The first is its impact on public issues and people who become its target. The second is policy implementation affects non-targeted group. The third is policy implementation influence the current condition and the future.

Food security has long become public policy instrument. Mears and Moeljanto (1982) argued this issue has not yet been solved since the Amangkurat era. Mubyarto (2002) state that agricultural sector, including rice in Indonesia, is not a solely scientific issue. It means rice production involves not only reproduction and economic issues, but also political and social issues. Thus, Mubyarto (2002) described three theoretical objectives of food security implementation, namely:

1. Stabilizing price of crops more particularly for farmers,

2. Improving farmer's income through better term of trade.

3. Providing direction and guidance on number of production.

Syafa'at (1996)'s study that run analysis on food policy and its impact towards public welfare based on welfare economics perspective identified several important elements, namely:

1. Real price of rice grain had negative influence towards demand of rice. $10 \%$ increase in the price of rice grain would decrease demand of rice by $6.5 \%$.

2. Real price of rice grain had positive influence towards rice production. $10 \%$ increase in the price of rice grain would increase production of rice by $6.5 \%$.

3. Rice grain demand is inelastic; every policy shifting the demand curve to the right, for example technology for qualified seeds, had tendency to decrease farmer's income because farmer's income resulting from increasing production is lower than that caused by decreasing price.

National food security sustainability according to Econit (2000) is called intertemporal benefit, which should be considered as"investment" instead of divestation. Both the Logistic Affair Agency and the government tend to treat rice commodity operation as money losing operations, compared to other commodities. Sajogyo (1999) mentioned that robust and sustainable food security will benefit the society. ".........unfortunately the government does not refer to macro-economic policy to discuss strategy to achieve food security. Macroeconomic policy can help the government analyzing supply and demand in order to achieve food security in household, regional and national level."

Adopting Mos'oed's review on Bates (1981)'s agricultural crisis that frequently happened in Africa, we can understand that series of process taking place in Africa actually have similar anasirs to ones Indonesian farmers are facing currently. The government is reluctantly to issue a policy that increases output due to political reasons. All business actors in agricultural sector, either those who are for or against the government, will benefit from the government policy that increases output (Mas'oed, 1999). 
The reality is stated in "group of theory" discussing policy as equilibrian (Truman, as cited in Dye, 1972: 23-25), showing that in HGD policy benefits consumer instead of producer or in the other words, the policy is consumer oriented.

\section{DISCUSSION OF RESULTS}

Food is one of the the most important national in national development programs. Being basic need for human-being, food is considered as means of survival and related to human welfare. Human being has always made effort to get food because their lives depend upon food.

The House of Representatives has issued the 2012 Decree number 18, new regulation related to food. Article 2 of this decree states that sovereignity, independence, resilience, security, benefits, equity, sustainability and justice are the principles or foundations of food implementation in Indonesia. This decree describes reducing dependence on food sources from foreign countries as one of the major purposes of the national development.

The decree emphasizes on two aspects, namely food sovereignty and food selfsufficiency. These two should be viewed as public decisions, political standpoints, statutes and policies. Objective of this policy is to improve productivity and food production (agriculture, livestock, as well as fisheries) optimumly, and strengthen national food reserves. It is expected to that the policy help farmers becoming qualified suppliers.

Direction of this policy is to achieve food sovereignty, food independence, and food security. Approaches or steps used to achieve these objectives, as stated in the 2012 Decree number 18 on food, will have a major impact on the Indonesian food market. As an example, taking food self-sufficiency as the main objective of this decree will likely result in a series of food policies that shift away from transparency in food trade. Article 34 on food exports and Article 36 on food imports represent these issues. Article 36 states that food insufficiency and/or inability to produce food article locally are the only conditions to import food. Article 34 to 40 describing export-import of food implies that balance between surplus and deficit is the only requirement for exporting and importing food. Unfortunately, the data on food article balance is far from accurate.

Based on the 2012 Decree number 18, food refers to processed or non-processed (natural) product of agriculture, plantation, forestry, fishery, livestock, or aquaculture and from water that human being consumed as food or beverage including food additives, raw materials, and other ingredients used in preparing, processing, and/or making food or beverage. Human-being depends heavily upon food to survive. Lack of food will decrease quality of life, cause some disease, famine and even disaster. Besides that, change of global climate has started increasing price of certain food commodity. Some international institutions have issued early reminder about food price fluctuation, and importance of national food security, food independence, and food sovereignity.

Food security, independence and sovereignity have their own definition. Food security refers to condition in which an individual and a country have adequate supply of qualified, safe, various, nutritious and accessible food. These food items should match religion, belief and culture exist in society and helps the community to live healthy, active, productive and sustainable lives. Food independence refers to ability of a country to use its natural, human, social and economic resource as well as local wisdom to produce diversedtype of food they need. Food sovereignity means government right to establish food-related policy independently in order to make sure all citizens have access towards food and give authority to the citizens to decide food system suitable with their local resources/ potentials (The 2012 Decree number 18).

Objective of food security is to increase availability of food, develop food diversification, developing food institutions and food business. There are several indicators of robust food security, namely:

Food Availability. One of the methods to provide accessible food for the society is food diversification, making sure different types of food are available to meet demand from the society. Another method is to help small, middle-scale and large industries in rural and urban 
areas to grow. Diversification is local source-oriented meaning that ideally food should be produced locally because it will boost local economy.

Food Accessibility. Food is basic rights for each Indonesian citizen since human being needs food to survive. Therefore, the government should guarantee there is adequate supply of safe, qualified, nutritious diversed and more importantly affordable food for Indonesian citizens. In addition, it is necessary to develop a food security system of which bases are diversed food resources, institutions and local cultures.

Consumer Acceptability. Food distribution or trade should meet certain requirements for food sanitation, maximum amount of food additives, contaminated residue, and standard procedure of food packaging. Another thing food producer should pay attention to is laboratory testing. Certain food items should pass laboratory testing prior to distribution.

Food Safety. Another significant factor is food safety. It refers to condition and effort to prevent food from biological and chemical pollution as well as other substances that have negative impact towards health.

People's Welfare. The most significant foundation of food security is food diversification. Other important elements to achieve food security are institution and domestic/local culture, food distribution and accessibility, and increasing amount of income. Creating conducive business climate, business opportunity and empowering cooperative and SMEs help the society getting better access to food.

Food security, food independence and food sovereignity are a whole concept in which food is available, affordable, and safe for consumption (Eriadi, 2012). Besides that, business actors and farmers as food producers will benefit from food-manufacturing business. At last, food should be distributed widely to all areas in Indonesia.

\section{CONCLUSION}

Taking how relevant the role of food for human being into account, Indonesian government should strive for providing sufficient and qualified food supply for its citizens. Adequate food supply will result in economic and national stability. Efforts to incrase production also aims to improve standard of living, create more jobs, develop level of intelligence and quality of life as well as create strong foundation for the following stage of national development.

As an addition, food security will result in decreasing amount of food import allowing the government to spend foreign exchange for other imported goods pivotal for the national development. Food supply and nutrition are two foundations to develop Indonesian human resource in the long-term. In relation to increasing standard of living and nutrition, food suply brings some consequence because of ever-increasing demand of food.

Food should ideally be available in sufficient amount and affordable price all over Indonesia. When the government has been able to realize this situation, food does not become complicated challenge. Nevertheless, food security still becomes major challenge for diversedcountries including Indonesia. Indonesia is known as agraris country because $60 \%$ of its citizens live in rural areas and work as farmers. The national food issues can be traced back to several elements and consumption.

\section{SUGGESTIONS}

It is vital for the government to make sure there is adequate supply of qualified food for its citizens. Food (rice) scarcity will automatically result in food supply, which may cause nutritional, social and even political crisis. One of the important elements of food security and sustainability is farmers. When farmers they can make living from farming, they will take care of their ricefield well and farmers will have tendency to quit farming when they feel they can no longer rely on farming as their source of income or do not get any support from the government. In order to realize food security, the government should establish some of the following policies:

- Sustainable policy on farmer's welfare; 
- Develop rural, regional and national food information system for famers;

- Conduct regional and national food distribution and food crisis mapping;

- Conduct regional and national food production mapping;

- Conduct monitoring in rural, regional and national level to make sure market mechanism run smoothly;

- Provide credit and capital farmers need to take care and develop their farm.

\section{REFERENCES}

1. Afandi, Andik, 2000, Evaluasi Kebijakan Harga Dasar Gabah: Studi Kasus Panen Raya Tahun 2000, JKAP Volume 4, Number 1 (May 2000).

2. Aufi Syata, 2006, Kliping Pangan dan Pertanian, Gadjah Mada Yoagyakarta.

3. Armadi, 2005, Strategi Pemasaran Beras, Usahawan, N0.04 TH.XXXIV APRIL, 2005.

4. Deptan. 2013. Program Peningkatan Ketahanan Pangan. [Terhubung Berkala]. http://www.deptan.go.id/daerah_new/ntt/distan_ntt/keg.apbn_files/PROGRAM\%20PENIN GKATAN\%20KETAHANAN\%20PANGAN.htm. 8 March $201 \overline{3}$.

5. Econit, 2000, Mayoritas Terlupakan: Tragedi Petani dan Anjloknya Harga Gabah, Econit's Public Policy Review, 2 (1) March.

6. Edward TTT, George C. 1999, Implementing Public Policy, Cungresional Quartely Pres, Washington.

7. Eriadi H. 2012. Peran Perekonomian Nasional Guna Ketahanan Pangan. [Terhubung Berkala]. http://hermawaneriadi.com/peran-perekonomian-nasional-guna-ketahananpangan/. 8 March 2013

8. Humas Deptan. 2012. Presiden Serukan Pentingnya Ketahanan dan Kemandirian Pangan Nasional. [Terhubung Berkala]. http://setjen.deptan.go.id/detailberita.php?id=447. 8 March 2013.

9. Islamy M.Irfan, 2004, Prinsip-prinsip Perumusan Kebijaksanaan Negara, Seventh Publication, Bumi Aksara.

10. Jafar Hafsah, 2006, Kedaulatan Pangan, Pustaka Sinar Harapan, Jakarta.

11. Nainggolan, Kaman, 2000, Ekonomi Beras: Antara Proteksi dan Pasar Bebas, Kompas 10 April.

12. Nakamura, Robert, T dan Smalwood, F., 1980, The Politics of Policy Implementation, Copyright, by St. Martin's Press Ine New York.

13. Wahab, S.Abdul, 1990, Analisis Kebijakansanaan Negara, First Publication, Rineka Cipta.

14. Winarno, Budi, 2004, Teori dan Proses Kebijakan Publik, Penerbit Medi Prosindo, Yogayakarta.

15. Mears, Leon A. and Sidik Moeljono, 1982, Kebijaksanaan Pangan, as cited in Anne Booth and Peter McCawley (eds): Ekonomi Orde Baru (Translator: Boediono).LP3ES, Jakarta.

16. Mubyarto, 2002, Masalah Beras di Indonesia, Center for Economic Studies Faculty of Economics UGM, Yogyakarta.

17. Putra IP, Ghozi M, Sudarto. 2008. Ketahanan Pangan Melalui Kearifan Lokal Di Desa Songgajah Kecamatan Kempo Kabupaten Dompu Ntb. Agricultural Technology Development Center of West Nusa Tenggara.

18. Sajogyo, 1999, Ketahanan Pangan dalam Pola Ketahanan Pertanian, Special Edition.

19. Suryana, Ahmad, 2003, Kapita Selekta Evolusi Pemikiran Kebijakan Ketahanan Pangan, Penerbit BPFE, Universitas Gadjah Mada, Yogyakarta.

20. Mas'oed. Mohtar, 19981, Politik dan Kebijakan Pertanian: Pelajaran dari Afrika, Reviu Buku: Robert H. Bates, Markets and states in tropical Afrika: the political basic of agricultural policy. Berkeley, CA: University of California Press.

21. Yudohusodo, Siswono. 2000, Beras Tak Kunjung Beres, Wartan Ekonomi, No.29/THN.XII/4-10 December 2000. 